\title{
BEACHROCKS CEMENT CHARACTERISTICS AND CONDITIONS OF FORMATION. CASE STUDY PLATANIAS BEACH, CHANIA, GREECE
}

\author{
Petropoulos A. ${ }^{1}$, Baziotis I. ${ }^{2}$, Anagnostou Ch. ${ }^{3}$ and Evelpidou N. \\ ${ }^{l}$ Faculty of Geology and Geoenvironment, National and Kapodistrian University of Athens, \\ Panepistimiopolis, 15784 Athens, Greece, alexandrospetrop@gmail.com,evelpidou@geol.uoa.gr \\ ${ }^{2}$ Agricultural University of Athens, Laboratory of Mineralogy and Geology, Athens, 11855 Greece, \\ ibaziotis@aua.gr \\ ${ }^{3}$ Institute of Oceanography, Hellenic Centre for Marine Research, $46.7 \mathrm{~km}$ Athens-Sounio Avenue, \\ Mavro Lithari, 19013 Anavyssos, Greece, chanag@hcmr.gr
}

\begin{abstract}
Beachrocks represents a coastal deposition in the intertidal area, and studying their properties may lead to create a model which identifies the conditions of their formation (paleo-environment). This paper focuses most intently on the cement material which is able to recover the paleo-environment conditions during diagenesis of such coastal sediment. We used optical microscopy, secondary electron microscopy and Raman Spectroscopy to characterize the cement texture, mineralogy and chemistry in the beachrocks. The existence of pure calcite primarily controlled by the meteorite water, while Mg-calcite appears between the lower meteoric and the upper marine phreatic zone. Finally, the presence of aragonite associated with the marine phreatic to lower marine vadose environment.

Keywords: beachrock, cement, aragonite, Mg-calcite, mineral chemistry.

\section{Пєрí $\eta \psi \eta$}

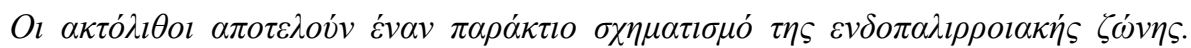

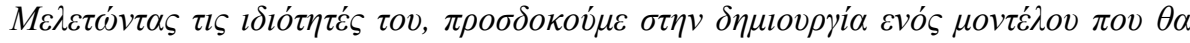

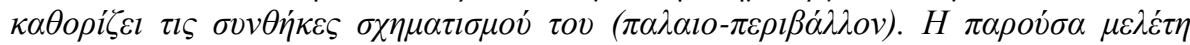

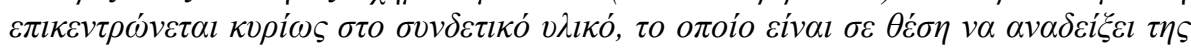

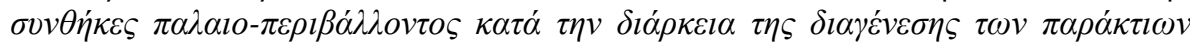

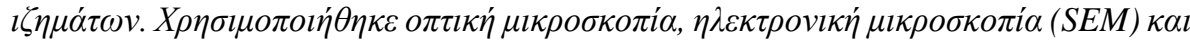

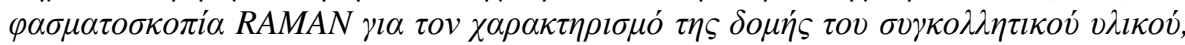

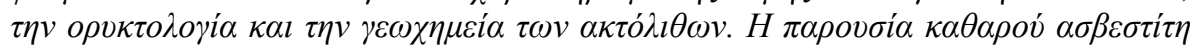

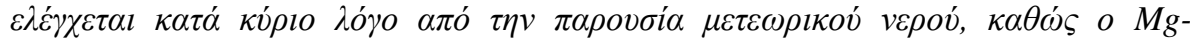

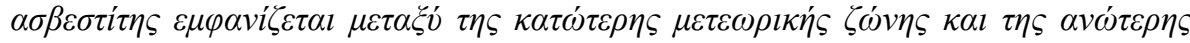

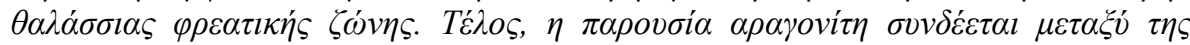

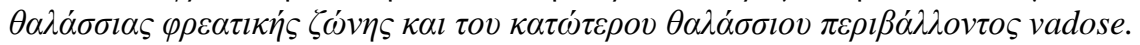

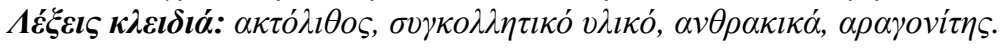




\section{Introduction}

Beachrocks provide critical information on the quaternary history including both sea-level changes, neotectonic deformation and processes like erosion in various coastal environments (Fouache et al. 2005; Kelletat, 2006; Desruelles et al., 2009; Thomas, 2009; Mourtzas, 2012; Mourtzas and Kolaiti, 2013; Stattegger et al., 2013; Mourtzas et al., 2014; Psomiadis et al,. 2014; Mauz et al., 2015). In principle, the beachrocks form in an intertidal environment, where an active mixing zone between meteoric and marine water leads to $\mathrm{pCO}_{2}$ decrease and carbonate saturation (Moore, 1973; Plummer, 1975; Meyers, 1987). Such rocks, represent coastal deposits suitable for identification of sea-level changes. Important information are gathered from the cement that surrounds the constituent mineral and lithic clasts of beachrock.

The major factor for the beachrock cement formation is the diagenesis process. The cement is the material that keeps in stable contact the different lithic clasts (Hanor, 1978). It depends mainly on water table elevation, temperature and pressure. Diagenesis involves processes such as dissolution, reprecipitation and recrystallization which ultimately lead to chemical stability. The process follows the relative thermodynamic stability of magnesian calcite and aragonite and the chemistry of the pore fluid (Morse and Mackenzie, 1990). Further, the criteria to identify the environment of beachrock formation are based on texture, mineral and chemistry of cement, along with the sedimentary structure (cf., Kelletat, 2006). The carbonate crystals of the cement are precipitate and grow within the pore space of the lithic clasts. According to Moore (1973), cementation process is mainly related with the pore fluid, which originates from the adjacent environments (e.g., hypersaline waters from sabkhas; meteoric water from ground water). In particular, a certain mineral like calcite, will formed when the solution is supersaturated with respect to this mineral and occurs during $\mathrm{pCO}_{2}$ decrease after degassing (Plummer, 1975; Meyers, 1987).

In this study we report the results of detailed micro-scale chemical and mineralogical analyses on the cement in two samples from the broad area of Chania bay (Crete, Southern Greece). Samples $\mathrm{ACH}$ VII(a) and A-CH 3 are rich in carbonate cement and contain rock fragments originating from the broad area. We used a range of complementary techniques optical microscope, secondary electron microscopy (SEM) and Raman Spectroscopy to characterize the minerals and cement in our samples. This paper focuses most intently at the forming conditions of the cement and the environmental conditions prevailing during the period of formation (etc. marine-phreatic zone, marine-vadose environment). We examine whether the crystals which growing at the pore space are pure of $\mathrm{Ca}$-carbonate or they contain some percentage of $\mathrm{Mg}$, event that is attested inland feeders. Finally, we propose a model which going to illustrating the coastal zones associated with the cement fabrics and the preferred carbonate geochemistry.

\section{Sampling areas - Description}

\subsection{Geological Setting}

For the purpose of the current study we used selected beachrocks from the broad area of Chania bay in Crete (Fig. 1). The Chania bay is situated on the north-western part of Crete and is presenting a variety of coastal landforms, which assist in the study of the factors involved in the formation and evolution of the coastline. The study area is bounded by Keritis basin at East and Tavronitis basin at West, which provides the coastline with appropriate materials for the formation of depositional coasts. Crete presents a complex geological area which is the result of geotectonic evolution as part of the active arc of the Aegean. It was estimated that 2-4 Ma ago, the area had an uplifted rate in the range $0.1-0.5 \mathrm{~mm} / \mathrm{yr}$; after that, it was speculated that the uplifted rate is $1-1.2 \mathrm{~mm} / \mathrm{yr}$ indicating acceleration in central and western Crete (Roberts et al., 2013). 


\subsection{Beachrocks}

The studied beachrocks are formed between the shoreface and beach (tidal zone), the chemically most active zone (mixing zone), in parallel-stratified beds, dipping to the sea with a gradient of $3-5^{0}$ and are composed mostly of sandstone alternating with conglomerate (Fig. 2). The beachrocks from Chania bay formed during the Holocene period. We collected 15 samples (limestones, conglomerates), including 5 beachrocks. The major criteria for the representativeness of the studied beachrocks (A-CH VII(a) and A-CH 3) were the freshness, the observed -even in hand specimencement surrounding the clasts and carbonate-rich material.

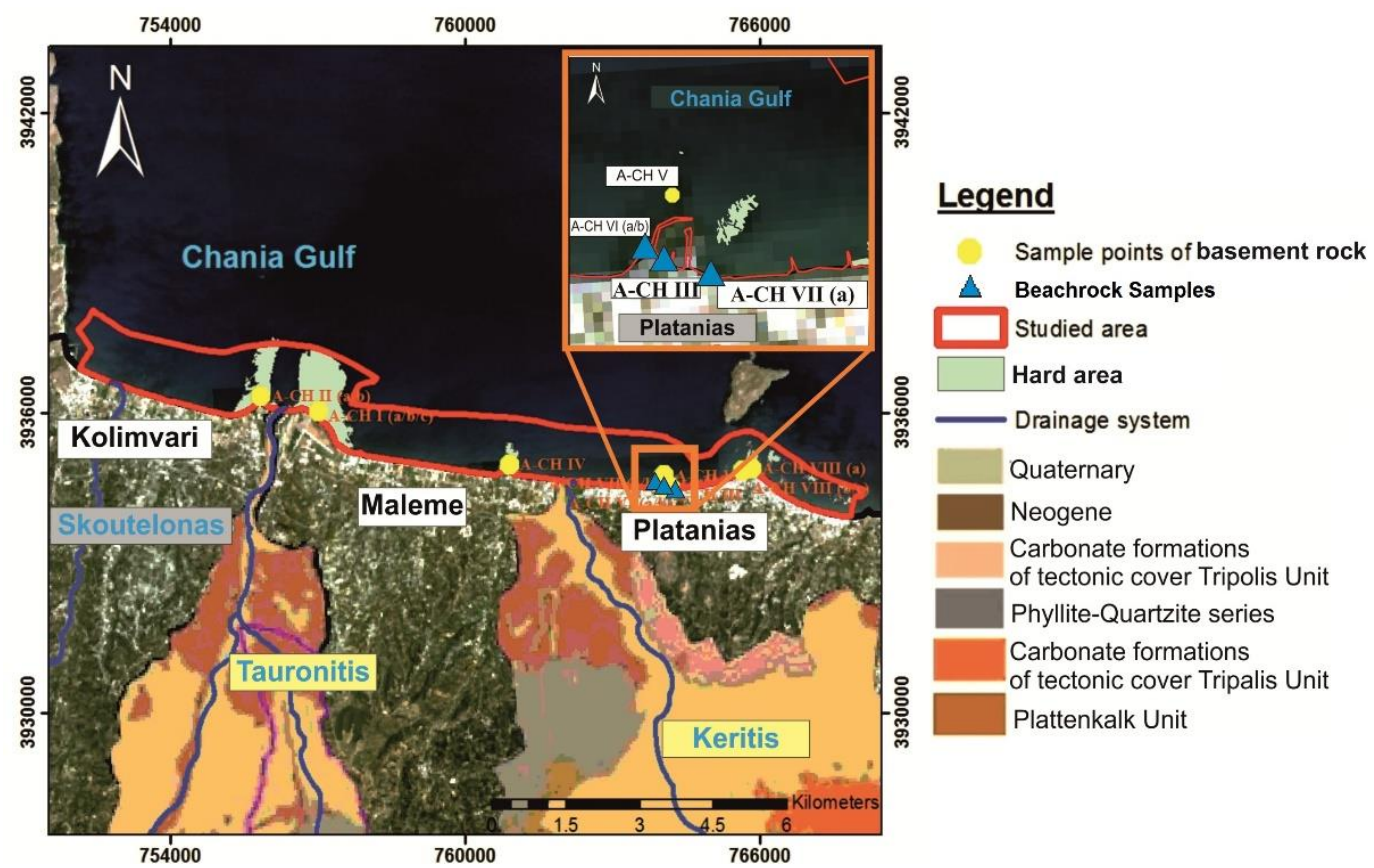

Figure 1 - Sketch map showing the location of Chania bay. Inset: Sample locations used in the present study.

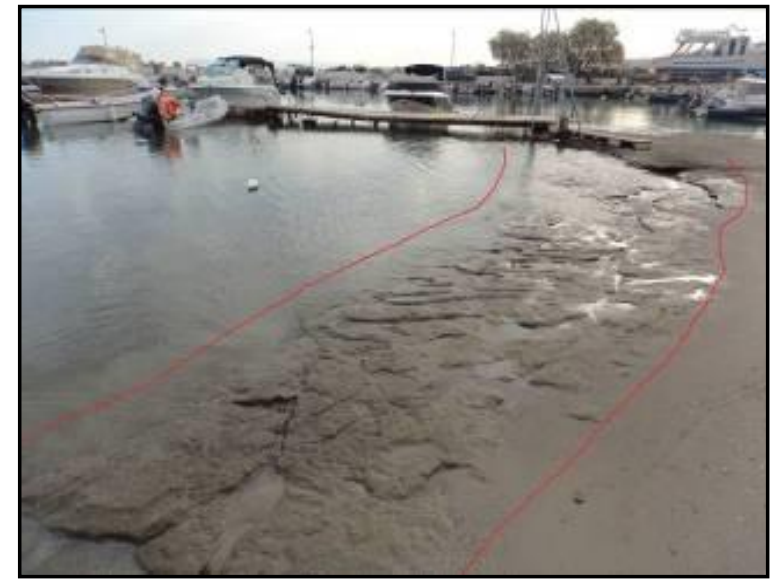

Figure 2 - Beachrocks displaying at Platanias port. Red thin line corresponds to the observed boundaries of the beachrock. 


\section{Analytical Methods}

\subsection{Secondary Electron Microscopy}

Characterization of the textural relationships, identification of the different mineral phases and semiquantitative major element determination of the cement were carried out in platinum-coated polished thin sections using a JEOL JSM 5600 Scanning Electron Microscopy (SEM) equipped with energydispersive spectrometer (EDS) at the Institute of Geology and Mineral Exploration (IGME) Athens (Greece). Operating conditions were: accelerating voltage $15 \mathrm{kV}$, beam current $20 \mathrm{nA}$ and 1-2 $\mu \mathrm{m}$ beam diameter. For minerals, a $20 \mathrm{nA}$ beam current and $20 \mathrm{~s}$ counting time on peak position were used. Representative mineral compositions are given in Table 1.

\begin{tabular}{|c|c|c|c|c|c|c|c|}
\hline Sample & \multicolumn{7}{|c|}{ A-CH VII(a) } \\
\hline Oxide (in wt.\%) & $1 i^{*}$ & 1ii & 2 & \multicolumn{2}{|c|}{3} & \multicolumn{2}{|c|}{4} \\
\hline $\mathrm{CaO}$ & 53.6 & 56.2 & 56.3 & \multicolumn{2}{|c|}{56.0} & \multicolumn{2}{|c|}{56.0} \\
\hline $\mathrm{MgO}$ & 2.43 & - & - & \multicolumn{2}{|c|}{-} & \multicolumn{2}{|c|}{-} \\
\hline Total & 56.0 & 56.2 & 56.3 & \multicolumn{2}{|c|}{56.0} & \multicolumn{2}{|c|}{56.0} \\
\hline \multicolumn{8}{|l|}{ \# of Ions } \\
\hline $\mathrm{Ca}$ & 0.94 & 1.00 & 1.00 & \multicolumn{2}{|c|}{1.00} & \multicolumn{2}{|c|}{1.00} \\
\hline$M g$ & 0.06 & 0.00 & 0.00 & \multicolumn{2}{|c|}{0.00} & \multicolumn{2}{|c|}{0.00} \\
\hline Sample & \multicolumn{7}{|c|}{ A-CH 3} \\
\hline Oxide (in wt.\%) & 1 & 2 & 3 & 4 & 5 & 6 & 7 \\
\hline $\mathrm{CaO}$ & 48.3 & 48.6 & 49.1 & 50.3 & 50.5 & 51.3 & 51.8 \\
\hline $\mathrm{MgO}$ & 7.25 & 6.94 & 6.38 & 5.2 & 4.96 & 4.24 & 3.7 \\
\hline Total & 55.5 & 55.5 & 55.5 & 55.5 & 55.5 & 55.5 & 55.5 \\
\hline \multicolumn{8}{|l|}{ \# of Ions } \\
\hline $\mathrm{Ca}$ & 0.83 & 0.83 & 0.85 & 0.83 & 0.88 & 0.9 & 0.91 \\
\hline$M g$ & 0.17 & 1.7 & 0.15 & 0.17 & 0.12 & 0.1 & 0.09 \\
\hline
\end{tabular}

\subsection{Raman Spectroscopy}

The Raman Spectroscopy (RS) was performed on the two samples in order to distinguish the carbonate mineral. RS spectra were collected at the National Hellenic Research Foundation, Institute of Theoretical and Physical Chemistry (Athens, Greece). The RS is equipped with a green excitation source of $514.5 \mathrm{~nm}$ and acquired at the $100-1500 \mathrm{~cm}^{-1}$ (Fig. 3).

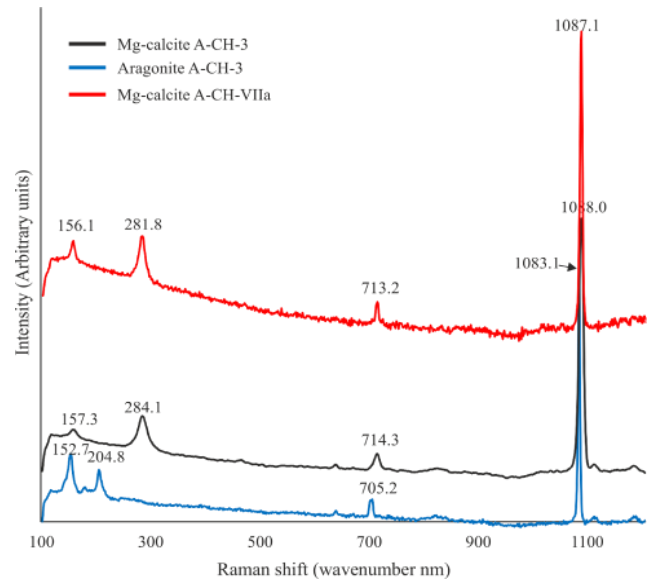

Figure 3 - Raman spectra of Mg-calcite and Aragonite from the studied samples. 
The RS of calcite has 3 main peaks at 282,712 and $1086 \mathrm{~cm}^{-1}$, but in our case the presence of $\mathrm{Mg}$ shifts the observed peaks toward higher wavenumbers (Fig. 3). For the aragonite, those peaks are at the 155, 207, 706, 1084, with our sample matching those values (Fig. 3).

\section{Petrography}

\subsection{Matrix}

The matrix of the samples are rich in carbonate and it develops at the pore space between the lithic clasts. At the sample A-CH VII(a) the classification of grain size described as well-sorted (low variance). The fine sandstone consists of carbonate grains (limestone), quartz grains and quartzfeldspar grains (gneiss); we noticed the presence of fossils as well (Fig. 4). At the sample A-CH 3 the classification of grain size described as moderately-sorted (moderately variance), and is composed of quartz-feldspar grains and quarts grains. Under the optical microscope, the cement was clearly displayed at the exterior part of grains (Fig. 4).
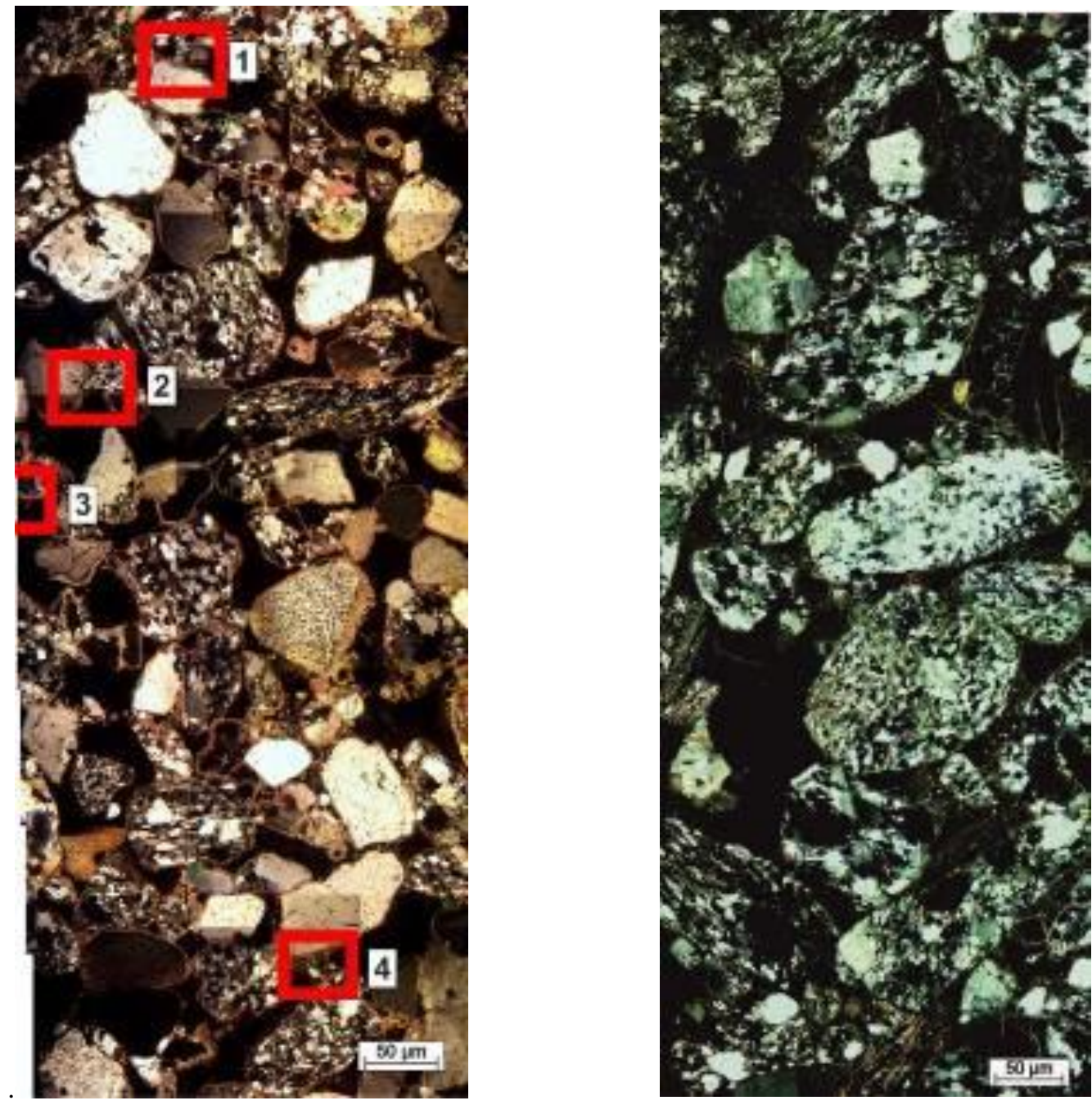

Figure 4 - (Left) Part of Mosaic from the sample A-CH VII(a); the analysed points indicated by numbers are also given at Table 1. (Right) Part of Mosaic from the sample A-CH 3. 


\subsection{Cement areas}

In sample A-CH VII(a) the cement material formed at the exterior part of the grain, exhibiting a variable thickness (Fig. 5). Additionally to that, the cement corresponds to carbonate, showing two distinct zones; the inner one is fine-grained and close to the grain, while the outer zone is coarser and away from the grain. In sample A-CH 3 the cement shows similar characteristics with the A-CH VII(a), with the exception of the presence of a single zone at the exterior part of the grains (Fig. 5).
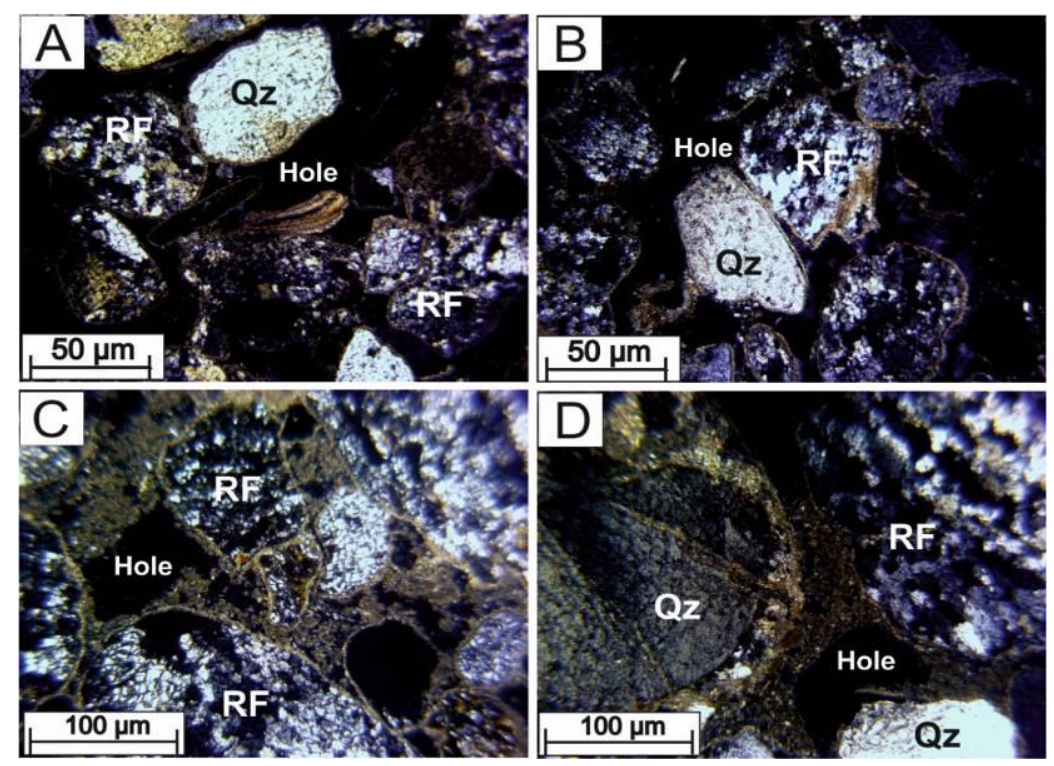

Figure 5 - (A-B), Fine sandstone consist of rock fragments, quartz (Qz) grains and fossils. The carbonate-rich cement corresponds to a thin layer around the grains. In (B) the grain size characterized as well-sorted. (C-D) Fine sandstone consist mainly of rock fragments and quartz. Also, carbonate cement with variable thickness surrounds all the grains. (A-B) Sample A-CH VII(a) and (C-D) Sample A-CH 3. RF: rock fragments, Qz: quartz.

\section{Results and Discussion}

Our analytical data on cement material (Figs. 6-8) are able to identify the spatial relationship between coastline and beachrock formation zone.

Although having similar petrographic composition the samples are totally different at the amount of $\mathrm{CaCO}_{3}$ at the cement; the sample A-CH VII(a) has a high content in the range of 94.1-100\%, while the sample A-CH 3 is enriched in magnesium with $\mathrm{CaCO}_{3}$ in the range of 82.7-91.0\%. The increased magnesium at the sample A-CH 3 is probably related with marine vadoze zone and/or marine phreatic zone (presence of aragonite). In contrast, the low-Mg sample A-CH VII(a) suggests either formation at the meteoric vadose zone and/or upper marine vadose zone.

The heterogeneous development of the cement surrounding the clasts and the presence of two cement zones in most clasts (with the inner zone being magnesium-rich compared to the outer) lead us to determine as the most possible forming environment the region between the upper phreatic marine zone and the lower meteoric vadose zone (Figs. 6-8).

It is important to notice the presence of aragonite at the sample A-CH 3; this is primarily formed at the phreatic - low marine vadose environment. Also, aragonite formation is related with the temperature of the solution; for example the higher the solution temperature, the faster aragonite precipitates relative to calcite (Burton and Walter, 1987) and the crystal form the cement takes is mostly fibrous. After that, we infer that the interplay between the different carbonate phases occur 
in the cement, and in particular, the content of calcite, aragonite or Mg-calcite, depends from the change in water-table elevation, the temperature or the pressure, with the view to chemical stability. One of the most effective ways to create polymorph of calcite and dolomite is the infiltration of meteoric water rich in dissolved $\mathrm{CO}_{2}$, depleting the cement in $\mathrm{Mg}, \mathrm{Sr}$ and $\mathrm{Na}$ and enriching it with other elements (e.g., $\mathrm{Fe}^{2+}$ ).

In case that the altitude of the sea level reduced, then the crystals of aragonite lead to dissolution and recrystallization in calcite and also high $\mathrm{Mg}$-calcite in low Mg-calcite. Crystal arrangement and fabric is controlled by environment and gravitation. High $\mathrm{Mg}$-calcite and aragonite form circum granular rim in meniscus fabric in the vadose environment or symmetrical crusts in the meteoric environment (Fig. 7).
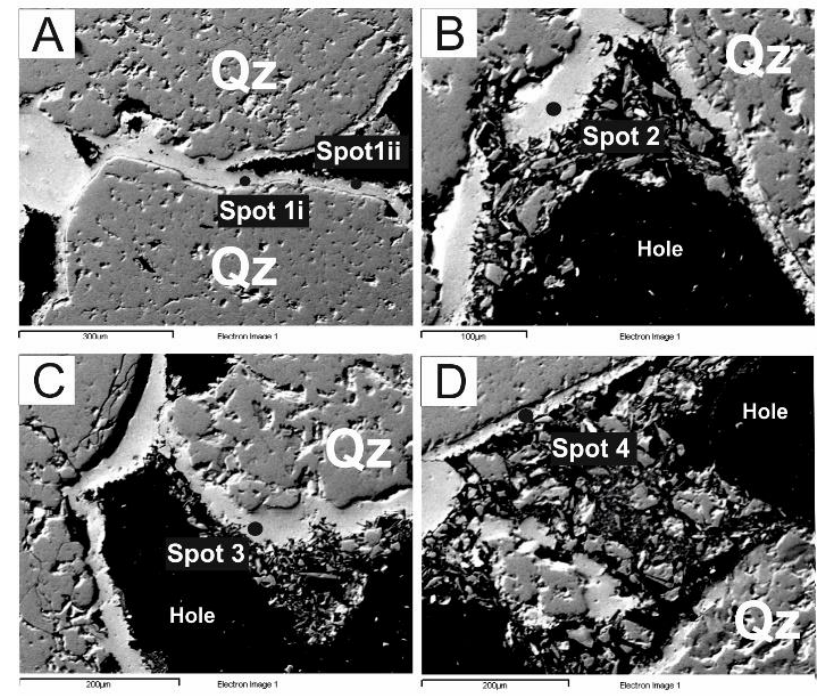

Figure 6 - Sample A-CH VII(a): (A) Heterogeneous formation of cement, composed by an outer - pure in $\mathrm{CaCO}_{3}$ - region (Spot 1), whereas toward the grain $\mathrm{Mg}$ is incorporated in the carbonate mineral (Spot 2), ( 2 zones of cement growth). (B - D) The constituent mineral of the cement is composed by pure $\mathrm{CaCO}_{3}(\mathrm{Spot} 3-5)$.
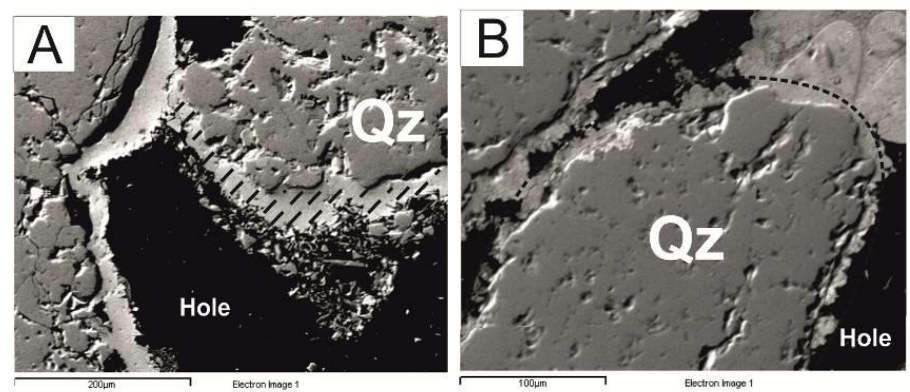

Figure 7 - The dashed lines represents (A) the granular rim in meniscus fabric in the vadose environment, and (B) the symmetrical crusts in the meteoric environment. 

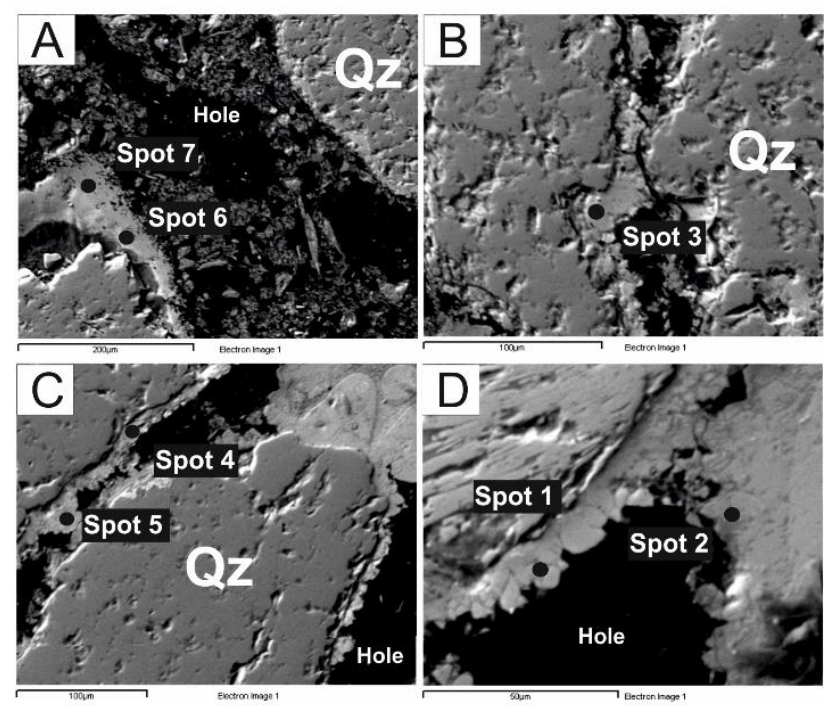

Figure 8 - Sample A-CH 3: The cement material is observed $\mathrm{CaCO}_{3}$ and $\mathrm{MgCO}_{3}$ with the only difference that from the outer zone to the inner we enrich in $\operatorname{Mg}$ (Spot 1 - 7).

Taking into account our data, we are able to create a case about the evolution of the beachrocks and their position in space. As such, the sample A-CH VII(a) formation occurs at the upper marine vadose environment indicated by high-Mg calcite ( $1^{\text {st }}$-inner- cement zone). Then the rock exposed at the meteoric vadoze environment, during of which the cement was made of pure to low-Mg calcite ( $2^{\text {nd }}$-outer- cement zone). In contrast, the sample A-CH 3, probably shows a deeper environment as indicated by the coexistence of $\mathrm{Mg}$-calcite and aragonite testifying a marine vadose environment. Further, toward the rim of the cement, the high-Mg calcite becomes progressively less rich in magnesium which is attributed to sitting at the meteoric vadose zone.

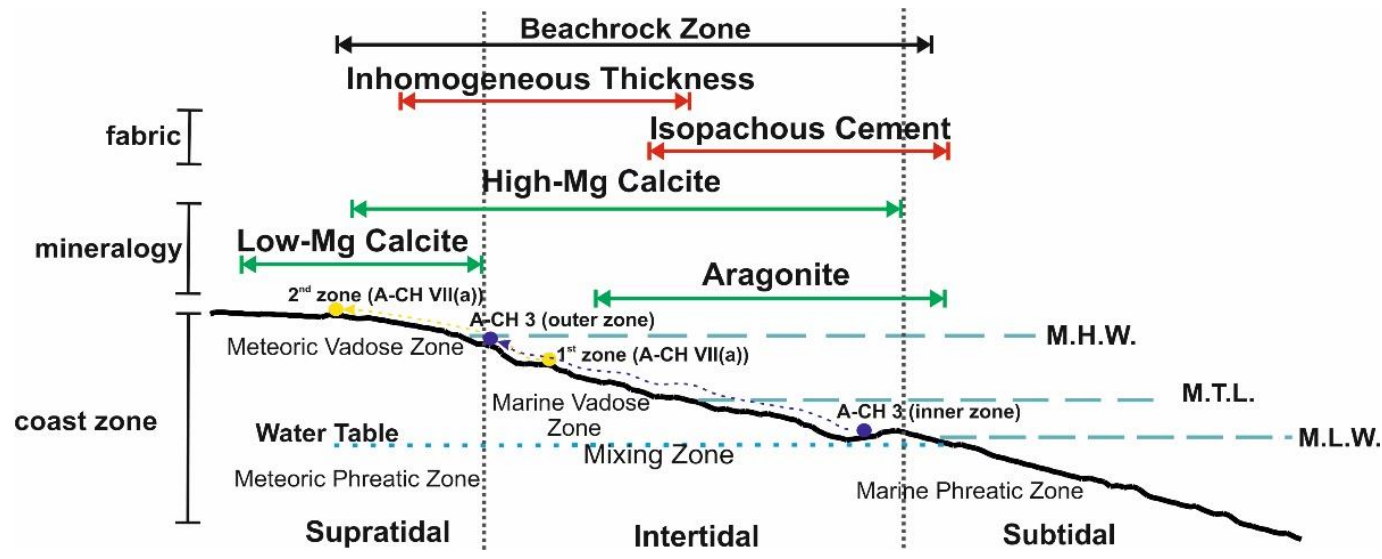

Figure 9 - Schematic illustration of coast zones, cement fabrics and mineralogy - Formation environments of the beachrocks from Platanias area is also included (M.H.W. Mean High Water Level, M.T.L. Mean Tidal Water Level, M.L.W. Mean Low Water Level) (Mauz et al., 2015).

The particular alternation of the composition environments, lead us to the conclusion that in the specific area is likely that have taken part two possible scenarios for the cement deposition. In the first scenario, considering that the beachrocks were formed in an uplifted area due to active tectonics, the area had changed diagenetic environment between the marine phreatic to meteoric vadose zone. 
An alternative scenario incorporates high flow rate of fresh water which in turn raise the water table level, switching the cement composition from deep to shallow environment. We tentatively suggest a combination of the two scenarios, however, we need to combine more structural, petrographical and geochemical data, to provide a robust model for the diagenetic evolution of the studied area. Finally, a likely reason for the uncovering of the beachrocks is the coastal erosion which initiated from the moment a fishing port was constructed at the area.

\section{Conclusions}

Several beachrocks were collected from the Platanias beach in Chania, Crete. We discuss the cementation history of beachrocks on the Platanias beach. The cement material is primarily composed by carbonate occurring in the form of pure calcite, $\mathrm{Mg}$-calcite and aragonite. These minerals resulted from two processes: 1) mixing of marine and underground waters and 2) vadose infiltration. Furthermore, Platanias beachrocks indicate two different zones relative to the coast, as inferred from the chemistry of the carbonate in cement. In particular, the presence of pure calcite related with the meteoric zone, while, the $\mathrm{Mg}$-calcite and aragonite related with marine environment; further, the Mg-calcite indicates more oxidizing conditions at the vadose zones, whereas aragonite prefers the phreatic zone. In conclusion, the studied materials verify that the beachrocks are being cemented by complex processes which primarily formed at a water mixing zone, of meteoric- and marine-origin.

\section{Acknowledgments}

Special thanks to the Institute of Geology and Mineral Exploration (IGME), the National Hellenic Research Foundation, Institute of Theoretical and Physical Chemistry, the laboratory of Economical Geology and Geochemistry, Department of Geology and Geo-environment, University of Athens, and the Hellenic Centre for Marine Research. Their help was decisive for the completion of this work.

\section{References}

Burton, E.A. and Walter, L.M., 1987. Relative precipitation rates of aragonite and Mg calcite from seawater: temperature or carbonate ion control? Geology, 15, 111-114.

Desruelles, S., Fouache, E., Ciner, A., Dalongeville, R., Pavlopoulos, K., Kosun, E., Coquinot, Y. and Potdevin, J., 2009. Beachrocks and sea level changes since Middle Holocene: comparison between the insular group of Mykonos-Delos-Rhenia (Cyclades, Greece) and the southern coast of Turkey, Global and Planetary Change, 66, 19-33.

Fouache, E., Desruelles, S., Pavlopoulos, K., Dalongeville, R., Coquinot, Y., Peulvast, J. and Potdevin, J., 2005. Using beachrocks as sea level indicators in the insular group of Mykonos, Delos and Rhenia (Cyclades, Greece), Zeitschriftfür Geomorphologie, 137, 37-43.

Hanor, J.S., 1978. Precipitation of beachrock cements: mixing of marine and meteoric waters vs. $\mathrm{CO}_{2}$-degassing, Journal of Sedimentary Research, 48, 489-501.

Kelletat, D., 2006. Beachrock as a sea-level indicator? remarks from a geomorphological point of view, Journal of Coastal Research, 22(6), 1555-1564.

Mauz, B., Vacchi, M., Green, A., Hoffmann, G. and Cooper, A., 2015. Beachrock: a tool for reconstructing relative sea level in the far-field, Marine Geology. http://dx.doi.org/10.1016/j.margeo.2015.01.009.

Meyers, W.J., 1987. Marine vadose beachrock cementation by cryptocrystalline magnesian calcite - Maui, Hawaii, Journal of Sedimentary Research, 57, 558-570.

Moore, C.H., 1973. Intertidal carbonate cementation, Grand Cayman, West Indies, Journal of Sedimentary Research, 43, 591-602.

Morse, J.W. and Mackenzie, F.T., 1990. Geochemistry of sedimentary carbonates, Developments in Sedimentology, 48, Elsevier, 707 pp. 
Mourtzas, N.D., 2012. A palaeogeographic reconstruction of the seafront of the ancient city of Delos in relation to Upper Holocene sea level changes in the central Cyclades, Quaternary International, 250, 3-18.

Mourtzas, N.D. and Kolaiti, E., 2013. Historical coastal evolution of the ancient harbor of Aegina in relation to the Upper Holocene relative sea level changes in the Saronic Gulf, Greece, Palaeogeography, Palaeoclimatology, Palaeoecology, 392, 411-425.

Mourtzas, N.D., Kissas, C. and Kolaiti, E., 2014. Archaeological and geomorphological indicators of the historical sea level changes and the related palaeogeographical reconstruction of the ancient foreharbor of Lechaion, East Corinth Gulf (Greece), Quaternary International, 332, 151-171.

Plummer, L.N., 1975. Mixing of sea water with calcium carbonate groundwater, Geological Society of America Memoirs, 142, 219-236.

Psomiadis, D., Albanakis, K., Zisi, N., Ghilardi, M. and Dotsika, E., 2014. Clastic sedimentary features of beachrocks and their palaeo-environmental significance: comparison of past and modern coastal regimes, International Journal of Sediment Research, 29, 260-268.

Roberts, G.G., White, N.J. and Shaw, B., 2013. An uplift history of Crete, Greece, from inverse modeling of longitudinal river profiles, Geomorphology, 198, 177-188.

Stattegger, K., Tjallingii, R., Saito, Y., Michelli, M., Thanh, N.T. and Wetzel, A., 2013. Mid to late Holocene sea-level reconstruction of Southeast Vietnam using beachrock and beach-ridge deposits, Global and Planetary Change, 110(B), 214-222.

Thomas, P.J., 2009. Luminescence dating of beachrock in the southeast coast of India-potential for Holocene shoreline reconstruction, Journal of Coastal Research, 25(1), 1-7. 